\title{
Peran mediasi keunggulan kompetitif pada faktor determinan kinerja bisnis UKM di sentra tenun batik di Jawa Tengah
}

\author{
Asyhari $^{1^{*}}$, Sri Hindah Pudjihastuti ${ }^{1}$, Dian Marhaeni Kurdaningsih ${ }^{2}$ \\ ${ }^{1}$ Program Studi Manajemen, Fakultas Ekonomi, Universitas Islam Sultan Agung \\ ${ }^{2}$ Program Studi Ilmu Komunikasi, Fakultas Bahasa dan Ilmu Komunikasi, Universitas Islam Sultan Agung \\ *Corresponding author: asyhari@unissula.ac.id
}

\begin{abstract}
Industry era 4.0 poses challenges for Small and Medium Enterprises (SMEs) to expand their business into the global market, but there are still many obstacles related to resources and technology readiness. This study aims to analyze the influence of business strategy quality, seller behavior ethics, process innovation, entrepreneurship orientation perspective, and business environment adaptability toward SMEs' business performance. This study uses a quantitative approach to investigate the mediation role of competitive advantage. The sample that used in this study is 80 SMEs' batik center entrepreneurs in Central Java, which taken uses purposive sampling method. The data are analyzed using Partial Least Square Structural Equation Modeling (PLS-SEM) with SmartPLS software. The results show that business strategy quality and seller behavioral ethics partially positive effect on competitive advantage. The second finding shows the business strategy quality, seller behavior ethic, process innovation, entrepreneurship orientation perspective, business environment adaptability, and partial competitive advantage positively affect business performance. This study expected contributes to the theoretical development, especially for strategic management.
\end{abstract}

Keywords: determinants of business performance, the mediating role of competitive advantage, Partial Least Square Structural Equation Modeling (PLS-SEM)

\begin{abstract}
Abstrak
Era Industri 4.0 menimbulkan tantangan bagi Usaha Kecil dan Menengah (UKM) untuk memperluas bisnis mereka ke pasar global, tetapi masih banyak kendala terkait kesiapan sumber daya dan teknologi. Penelitian ini bertujuan untuk menganalisis pengaruh kualitas strategi bisnis, etika perilaku penjual, inovasi proses, perspektif orientasi kewirausahaan, dan adaptasi lingkungan bisnis terhadap kinerja bisnis UKM. Penelitian ini menggunakan pendekatan kuantitatif untuk menyelidiki peran mediasi keunggulan kompetitif. Sampel yang digunakan dalam penelitian ini adalah 80 pengusaha UKM di pusat batik Jawa Tengah, yang diambil menggunakan metode purposive sampling. Data dianalisis menggunakan Partial Least Square Structural Equation Modeling (PLS-SEM) dengan perangkat lunak SmartPLS. Hasil penelitian menunjukkan bahwa kualitas strategi bisnis dan etika perilaku penjual secara parsial berpengaruh positif terhadap keunggulan bersaing. Temuan kedua menunjukkan kualitas strategi bisnis, etika perilaku penjual, inovasi proses, perspektif orientasi kewirausahaan, kemampuan beradaptasi lingkungan bisnis, dan keunggulan kompetitif parsial berpengaruh positif terhadap kinerja bisnis. Penelitian ini diharapkan berkontribusi pada pengembangan teoritis, terutama untuk manajemen strategis.
\end{abstract}

Kata Kunci: determinan kinerja bisnis, peran mediasi keunggulan kompetitif, PLS-SEM

JEL: M0

DOI: $10.20885 /$ jsb.vol22.iss2.art1

\section{Pendahuluan}

Usaha Kecil dan Menengah (UKM) Indonesia mempunyai peran strategis dalam pembangunan nasional. Fakta menunjukkan UKM terbukti mampu meningkatkan pertumbuhan ekonomi (Faisal, Hermawan, \& Arafah, 2018; Sijabat, 2018), menyerap tenaga kerja (Sarwoko, 2008; Tambunan, 2011), tahan menghadapi krisis ekonomi global (Irjayanti \& Azis, 2012; Sukesti \& Iriyanto, 2011), 
Peran mediasi keunggulan kompetitif pada faktor determinan

kinerja bisnis UKM di sentra tenun batik di Jawa Tengah

dan berkontribusi terhadap Product Domestic Bruto (Sarwoko, 2008). UKM memiliki persentase sebesar 99,99\% dari total keseluruhan pelaku di Indonesia, dan menyumbang Product Domestic Bruto (PDB) sekitar 60\% (Bank Indonesia, 2015). Perkembangan jumlah UKM juga terus mengalami peningkatan. Khusus di Jawa Tengah pada tahun 2017 tumbuh sebesar 4,35\%, dari 115.751 unit di tahun 2016 menjadi 120.781 unit tahun 2017. Kinerja penjualan (omset) juga meningkat sebesar 3,59\%, dari Rp.43.570 Milyar menjadi Rp.45.132 Milyar (www.dinkop-umkm.jatengprov.go.id, 2018).

Salah satu UKM yang mengalami perkembangan pesat adalah industri kreatif. Data menunjukkan nilai ekspor ekonomi kreatif terus meningkat dari tahun ke tahun, yaitu sebesar US\$13.507,0 (2010), US\$15.641,4 (2011), US\$15.439,6 (2012), US\$15.870,6 (2013), US\$18.164,9 (2014), US\$19.364,1 (2015), dan 19.988,9 di tahun 2016. Sub sektor industri fashion memiliki berkembang paling pesat. Meskipun pada tahun 2012 mengalami penurunan sebesar 2,63 persen, tahun 2013 dan 2014 mengalami peningkatan sebesar 5,05 persen dan 1,00 persen hingga nilainya mencapai US\$10.698,8 juta. Pada tahun 2015 nilai ekspor subsektor fashion meningkat 1,84 persen dengan berat bersih mencapai 650,4 ribu ton. Peningkatan ekspor produk fashion kembali terjadi di tahun 2016 sebesar 0,06 persen dengan nilai US\$10.901,5 juta dan memberikan kontribusi sebesar 54,54 persen terhadap total nilai ekspor sektor ekonomi kreatif (Retas, 2017).

UKM memiliki tantangan berat untuk mengembangkan usahanya memasuki pasar global pada era industri 4.0. Temuan studi Tambunan (2011) menjelaskan kendala utama UKM adalah kesulitan keuangan, kurangnya pemasaran, rendahnya tingkat pendidikan, budaya, dan kemampuan inovasi. Studi Ismanto, Aziz, \& Irawan (2018) menyatakan permasalahan yang dihadapi UKM industri kreatif antara lain: kuantitas dan kualitas sumber daya insani, iklim kondusif untuk memulai dan menjalankan usaha, penghargaan/partisipasi, percepatan tumbuhnya teknologi informasi dan komunikasi, serta lembaga pembiayaan.

Untuk memperoleh kinerja bisnis yang tinggi, inovasi produk UKM perlu terus dilakukan. Penelitian Hadiyati (2011) menghasilkan temuan inovasi berpengaruh positif signifikan terhadap kewirausahaan usaha kecil. Hasil studi Ilyas, Munir, \& Sobarsyah (2017) menunjukkan inovasi berdampak positif terhadap kinerja UKM di Sulawesi Utara. Namun hasil studi Lita, Muthia, \& Faisal (2018a) menyatakan inovasi produk tidak berpengaruh signifikan terhadap kinerja perusahaan.

Para peneliti menjelaskan keterkaitan orientasi kewirausahaan dalam meningkatkan kinerja perusahaan (Gunawan, Jacob, \& Duysers, 2013; Ismanto et al., 2018; Kumalaningrum, 2012; Masuci, 2010; Wardoyo, Rusdianti, \& Purwantini, 2015). Namun studi lain menunjukkan orientasi kewirausahaan tidak berpengaruh terhadap kinerja perusahaan (Ali \& Ali, 2014; Echdar, 2012; Hatta, 2015; Suci, 2009). Peningkatan kinerja perusahaan juga perlu ditunjang dengan kualitas strategi bisnis (Wardoyo, Rusdianti \& Purwantini, 2015; Widodo, 2011). Namun temuan studi Suci (2009) menjelaskan strategi bisnis berpengaruh negatif terhadap kinerja usaha UKM bordir di Jawa Timur. Demikian halnya hasil studi Wardi, Mangunwihardjo, \& Perdana (2016) mengungkapkan strategi bisnis tidak terbukti berpengaruh signifikan pada kinerja perusahaan UKM makanan di Kota Semarang.

Choi (2014) mengatakan kemampuan beradaptasi sangat penting untuk kelangsungan hidup setiap organisasi mengingat lingkungan yang tidak pasti. Temuan penelitian menjelaskan adaptabilitas lingkungan berdampak pada kinerja perusahaan (Mulyanto \& Sugiarti, 2017; Setyawati \& Helmy, 2018; Widodo, 2011; Wulandari, 2009). Hasil penelitian Sutono (2005) menunjukkan semakin tinggi perilaku etis maka semakin meningkat kinerja penjualan.

Berdasarkan fenomena bisnis UKM di Indonesia dan research gap pada penelitian terdahulu, studi ini menganalisis peran mediasi keunggulan kompetitif pada faktor-faktor penentu kinerja bisnis UKM. O'Donnell, Gilmore, Carson \& Cummins (2002) menyatakan bahwa terjadi peningkatan perhatian penelitian pada konsep keunggulan kompetitif, namun masih berfokus pada perusahaan besar saja, padahal model keunggulan kompetitif tersebut tidak sepenuhnya sesuai untuk perusahaan yang lebih kecil. Meskipun beberapa literatur menyatakan peran penting keunggulan kompetitif pada kinerja bisnis UKM (Singh, Garg, \& Deshmukh, 2009; Ab Rahman \& Ramli, 2014; Djodjobo \& Tawas, 
2014; Setyawati \& Abrilia, 2013; Soepandi, 2017), akan tetapi belum menjelaskan bagaimana hubungan yang terjadi.

Tujuan dari penelitian ini adalah untuk menguji bukti empiris pengaruh kualitas strategi bisnis, etika penjual, inovasi proses, adaptabilitas lingkungan, keunggulan kompetitif terhadap kinerja bisnis UKM industri kreatif di Jawa Tengah. Penelitian ini diharapkan berkontribusi pada literatur manajemen strategi dengan menjabarkan definisi dan pengukuran konstruk keunggulan kompetitif secara lebih luas.

\section{Tinjauan Literatur dan Hipotesis}

\section{Hubungan Strategi Bisnis dengan Keunggulan Kompetitif dan Kinerja Bisnis}

Untuk mencapai daya saing, usaha kecil dan menengah (UKM) perlu mempertimbangkan strategi inovasi, strategi teknologi informasi, jaringan dan strategi cluster. UKM perlu melakukan strategi inovasi dengan berinvestasi dalam pengetahuan baru sebagai strategi daya saing (Rahayu \& Purwani, 2012). Strategi bisnis yang terbaik dapat meningkatkan kinerja bisnis, memenangkan persaingan dan mempertahankan pangsa pasar agar tidak diambil pesaing. Strategi bisnis untuk mencapai tingkat keberhasilan tinggi dalam mengungguli pesaing yang dapat dipilih meliputi: keunggulan biaya, strategi diferensiasi dan strategi fokus (Nur, Surachman, Salim \& Djumahir, 2014).

Studi terdahulu Calantone, Kim, Schidt, \& Cavusgil (2006) menunjukkan strategi bisnis merupakan faktor penentu keunggulan kompetitif. Menggunakan data dari manajer di negara Amerika Serikat, Korea, dan Jepang, temuan menunjukkan strategi adaptasi produk secara positif terkait dengan kinerja ekspor. Penelitian Sarwoko (2008) pada UKM di wilayah Kabupaten Malang menghasilkan temuan bahwa strategi bisnis berpengaruh terhadap keberhasilan usaha. Hasil penelitian Amirkhani \& Reza (2015) menunjukkan ada hubungan signifikan antara orientasi strategis dan strategi bisnis sehingga mempengaruhi kinerja perusahaan perbankan di Teheran. Munandar (2016) menyatakan strategi replikasi yang meliputi kerjasama pemerintah, lembaga swadaya masyarakat, swasta dan individu maupun kelompok yang dikelola secara efektif dalam bentuk kemitraan, perlu didesain secara tepat untuk memanfaatkan sumber daya alam dan sumber daya manusia untuk memasuki pasar era global. Berdasarkan uraian tersebut dapat diajukan hipotesis:

H1a: Kualitas Strategi Bisnis berpengaruh positif terhadap keunggulan kompetitif

H1b: Kualitas Strategi Bisnis berpengaruh positif tidak langsung terhadap kinerja bisnis

\section{Hubungan Etika Perilaku Penjual dengan Keunggulan Kompetitif dan Kinerja Bisnis}

Etika perilaku menurut Lin \& Wu (2012) adalah perilaku etis dianggap sebagai hubungan timbal balik berdasarkan pertukaran yang adil, pelanggan merasakan hubungan yang menguntungkan, dan tindakan yang memungkinkan umpan balik diambil. Penjual dengan etika yang baik dapat membangun hubungan yang baik dengan pelanggan. Apabila penjual memberikan informasi yang benar maka pelanggan akan lebih puas dengan layanan, sehingga meningkatkan kepercayaan dan kepuasan, dan akan diikuti dengan rekomendasi dari mulut dan mulut. Perilaku penjualan etis diukur penjual tidak hanya tertarik pada kepentingan sendiri namun pada kepentingan pelanggan, penjual tidak membesar-besarkan fitur dan manfaat kebijakannya, dan penjual tidak berbohong tentang berkompetisi untuk melakukan penjualan.

Beberapa studi menggarisbawahi bahwa etika perilaku dapat meningkatkan keunggulan kompetitif (Aziza, Aziz, Mohtar, \& Othman, 2017). Hasil studi Lin \& Wu (2012) menunjukkan perilaku penjualan etis berpengaruh positif pada kepuasan pelanggan, dan berdampak mengurangi biaya transaksi yang diperlukan. Temuan penelitian Chen \& Mau (2009) menunjukkan perilaku penjualan etis tenaga penjualan memainkan peran penting dalam memenangkan loyalitas dan kepercayaan pelanggan terhadap perusahaan. Perilaku penjual untuk konsisten, kompeten, jujur, adil, bertanggung jawab, dan baik hati akan mempengaruhi persepsi pelanggan terhadap perusahaan. Hasil studi Wu (2002) menguatkan bahwa sebuah perusahaan apabila berniat meningkatkan etika bisnis 
yang dipraktekkan lebih tinggi, maka akan meningkatkan kinerja organisasinya lebih tinggi. Oleh karenanya dapat diajukan hipotesis:

H2a: Etika perilaku penjual berpengaruh positif terhadap keunggulan kompetitif

$\mathrm{H} 2 \mathrm{~b}$ : Etika perilaku penjual berpengaruh positif tidak langsung terhadap kinerja bisnis

\section{Hubungan Inovasi Proses dan Kinerja Bisnis}

Studi tentang inovasi proses telah menarik para peneliti selama beberapa dekade (Choi, 2014; GarcíaRodríguez, Gil-Soto, Ruiz-Rosa, \& Gutiérrez-Taño, 2017; Han, Kim, \& Srivastava, 1998; Jansen, Van Den Bosch, \& Volberda, 2006; Jermias, 2006; Kirca, Jayachandran, \& Bearden, 2005; Putri, Yasa, \& Rahyuda, 2016; Reinartz, Krafft, \& Hoyer, 2010). Hasil penelitian Sutopo \& Sutono (2004) menunjukkan inovasi berpengaruh positif terhadap kinerja yang sangat baik dan kompetitif. Aini, Long Shen, Musadieq, \& Handayani (2013) mengungkapkan bahwa usaha kecil menengah membutuhkan kemampuan inovasi yang kuat untuk mencapai keunggulan kompetitif. Hal ini mengingat peran pentingnya kemampuan inovasi pada peningkatan kinerja bisnis. Hasil studi Rum (2013) menjelaskan kemampuan inovasi memiliki berdampak positif secara signifikan pada kinerja bisnis, sedangkan hasil penelitian Lita, Muthia \& Faisal (2018b) menyimpulkan penerapan inovasi terkait dampaknya terhadap keberlanjutan UKM di masa depan. Berdasarkan uraian tersebut, maka hipotesis yang diusulkan adalah:

H3: Inovasi proses berpengaruh positif terhadap kinerja bisnis

\section{Hubungan Orientasi Kewirausahaan dan Kinerja Bisnis}

Orientasi kewirausahaan dalam sebuah usaha memegang peranan penting dalam memperoleh kinerja bisnis (Mahmoud, 2018). Menurut Rauch, Wiklund, Lumpkin, \& Frese (2009) inovasi kewirausahaan merupakan keinginan pengusaha untuk mendorong dan mendukung kreativitas dalam bentuk peluncuran produk atau layanan baru atau lebih baik. Hughes \& Morgan (2007) menjelaskan inovasi memungkinkan perusahaan untuk membedakan produknya dari para pesaing. Hussain, Ismail, \& Shah (2015) menjelaskan dalam lingkungan bisnis yang kompetitif, perusahaan yang tidak berorientasi kewirausahaan akan menghilang dari pasar dalam waktu singkat. Organisasi yang bertindak secara kewirausahaan berada dalam posisi lebih baik dalam beradaptasi dalam lingkungan bisnis yang berubah. Orientasi kewirausahaan memungkinkan perusahaan untuk mencari dan memanfaatkan peluang pasar-pasar di mana pesaing belum tercapai, mengambil risiko dan memperkenalkan produk baru untuk mencapai keunggulan kompetitif yang berkelanjutan.

Berkenaan dengan hal di atas, hasil studi Hussain et al. (2015) menyatakan orientasi wirausaha yang tersusun atas dimensi pengambilan risiko, proaktif dan inovasi, berpengaruh positif signifikan terhadap kinerja UKM di Malaysia. Studi lanjutan Hussain, Abbas, \& Khan (2017) mengungkapkan bahwa orientasi kewirausahaan dan kinerja organisasi berhubungan satu sama lain. Hasil penelitian Palalic \& Busatlic (2015) menyimpulkan agar memiliki pertumbuhan bisnis yang lebih cepat, UKM di Bosnia Herzegovia harus memasukkan inovasi, proaktif dan pengambilan risiko. Hasil studi Gupta \& Batra (2016) mengungkapkan hubungan positif yang kuat antara orientasi kewirausahaan dan kinerja perusahaan UKM di India. Studi Bashor \& Purnama (2017) menjelaskan orientasi kewirausahaan berdampak positif terhadap kinerja bisnis dan keunggulan bersaing manajer UKM industri sepatu di Mojokerto Jawa Timur. Temuan studi Ilyas et al (2017) menyatakan orientasi kewirausahaan dalam bentuk kebutuhan pencapaian, kemandirian dan upaya ekstra mempengaruhi kinerja UKM di Sulawesi Selatan. Berdasarkan uraian tersebut, maka hipotesis yang diusulkan adalah: H4: Perspektif orientasi kewirausahaan berpengaruh positif terhadap kinerja bisnis

\section{Hubungan Adaptabilitas Lingkungan Usaha dan Kinerja Bisnis}

Adaptabilitas terhadap perubahan lingkungan menjadi prasyarat agar perusahaan dapat meningkatkan kinerja bisnis (Mulyanto \& Sugiarti, 2017). Hasil studi Arif \& Widodo (2011) 
mengungkapkan adaptabilitas berpengaruh terhadap kinerja organisasi, bahwa untuk meningkatkan kinerja perusahaan maka harus dibangun adaptabilitas. Kompleksitas dan dinamika lingkungan eksternal merupakan pemicu kinerja organisasi di negara berkembang. Adaptabilitas lingkungan sebagai derajat penyesuaian perubahan dan ketidakstabilitas lingkungan dalam industri, mampu memoderasi pengaruh orientasi kewirausahaan dan kreativitas program dalam meningkatkan kinerja pemasaran (Arif \& Widodo, 2011). Berdasarkan uraian tersebut maka dikembangkan hipotesis:

H5: Adaptabilitas lingkungan usaha berpengaruh positif terhadap kinerja bisnis.

\section{Hubungan Keunggulan Kompetitif dan Kinerja Bisnis}

Keunggulan kompetitif diartikan berkaitan dengan cara bagaimana perusahaan memilih dan melaksanakan strategi generik ke dalam praktek. Keunggulan bersaing merupakan determinan utama bagi kinerja perusahaan (Porter, 2008). Keunggulan diferensiasi produk dan layanan merupakan dorongan utama kinerja pemasaran perusahaan (Ferdinand, 2003). Setyawati \& Abrilia (2013) menyatakan agar perusahaan memperoleh keuntungan dari penerapan strategi, maka harus melalui keunggulan bersaing. Mulyanto \& Sugiarti (2017) menjelaskan agar tidak tergerus oleh persaingan globalisasi, maka organisasi bisnis harus menciptakan strategi bersaing agar memiliki kinerja terbaik.

Temuan studi Purnama \& Setiawan (2003) menunjukkan bahwa keunggulan bersaing bidang pemasaran atau kompetensi pemasaran memiliki pengaruh positif terhadap kinerja perusahaan dalam bentuk pangsa pasar dan pertumbuhan pasar. Studi Teeratansirikool, Siengthai, Badir, \& Charoengam (2013) menemukan, secara umum semua strategi bersaing berpengaruh meningkatkan kinerja perusahaan, meskipun strategi diferensiasi perusahaan tidak memiliki dampak langsung terhadap kinerja perusahaan. Berdasarkan uraian tersebut hipotesis dikembangkan dalam penelitian ini adalah: H6: Keunggulan kompetitif berpengaruh positif terhadap kinerja bisnis

\section{Peran Mediasi Keunggulan Kompetitif}

Pada bagian ini peneliti mengembangkan proposisi kunci bahwa keunggulan kompetitif memediasi dampak kualitas strategi bisnis, dan etika perilaku penjual terhadap kinerja bisnis UKM. Menurut Porter (2008) keunggulan kompetitif berhubungan dengan metode bagaimana perusahaan memilih dan melaksanakan strategi ke dalam praktik. Selanjutnya Purnama \& Setiawan (2003) berpendapat sumber keunggulan bersaing adalah keterampilan, sumber daya dan pengendalian yang superior. Keterampilan mencakup kemampuas teknis, manajerial dan operasional. Pada akhirnya sumbersumber keunggulan bersaing tersebut diharapkan dapat meningkatkan profitabilitas perusahaan yang berupa perluasan pangsa pasar, pertumbuhan penjualan dan laba, serta peningkatan jumlah pelanggan.

Peran mediasi keunggulan kompetitif pada kinerja bisnis UKM telah dijelaskan pada studi sebelumnya oleh Zhou, Brown, \& Dev (2009), Yacob, Octavia, Mayrina \& Hasan (2017), dan diperkuat penelitian Nurlina \& Darsono (2017). Temuan studi Sutapa, Mulyana, \& Wasitowati (2017) menyatakan inovasi memiliki pengaruh yang signifikan terhadap keunggulan dan kinerja kompetitif, dan selanjutnya, keunggulan kompetitif memiliki pengaruh yang signifikan terhadap kinerja perusahaan. Studi Tobing, Fathorazz \& Wulandari (2018) menemukan bahwa kemampuan inovasi merupakan faktor yang secara signifikan mempengaruhi keunggulan kompetitif UKM di Jawa Timur. Menggunakan metode analisis regresi berganda, hasil studi menyimpulkan semakin tinggi kemampuan inovasi, fokus pada strategi bisnis, dan respon terhadap perubahan yang terjadi, semakin memperkuat keunggulan kompetitif UKM (Tobing et al., 2018). Pengujian peran mediasi keunggulan kompetitif dalam studi ini dilakukan secara lebih komprehensif, yaitu melalui metode analisis Partial Least Square Structural Equation Model (PLS-SEM).

Berdasarkan tinjauan teoritis dan pengembangan hipotesis, maka peran keunggulan kompetitif pada faktor determinan kinerja bisnis dapat dijelaskan pada Gambar 1. 


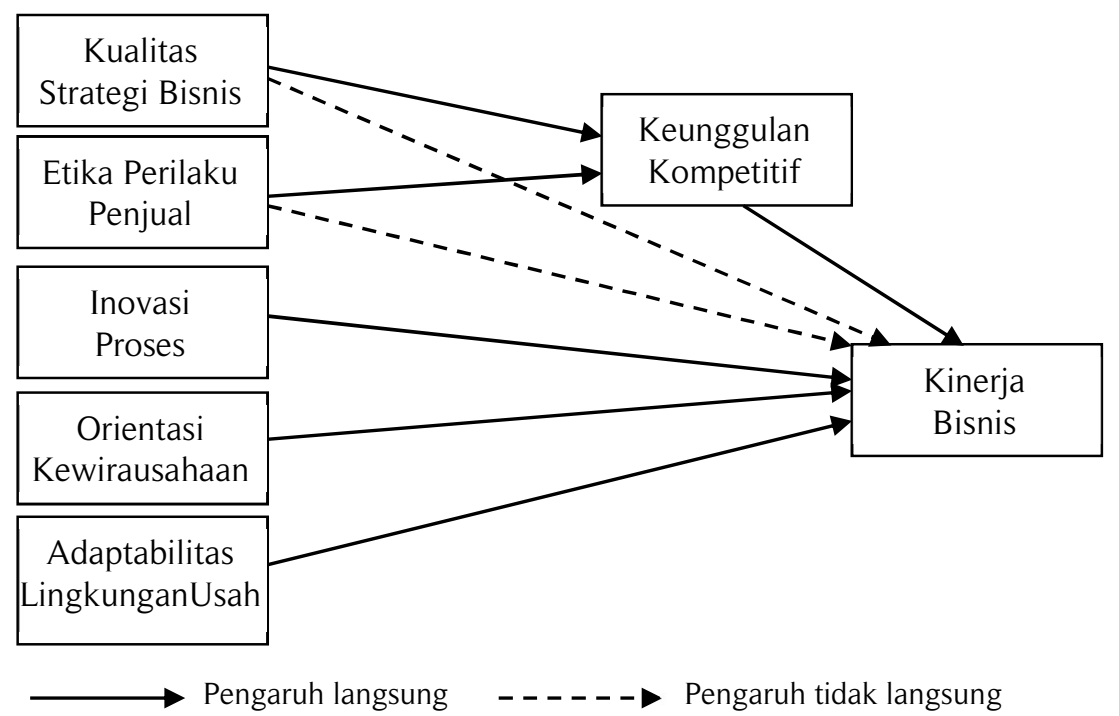

Gambar 1. Rerangka Pemikiran Penelitian

\section{Metode Penelitian}

\section{Jenis Penelitian}

Studi ini termasuk dalam jenis penelitian eksplanatori yang bertujuan untuk mengalisis hubunganhubungan antara satu variabel dengan variabel lainnya, atau bagaimana suatu variabel mempengaruhi variabel lainnya (Sekaran, 2006). Metode kuantitatif dipilih dalam studi ini karena telah memenuhi kaidah-kaidah ilmiah yaitu kongkrit/empiris, obyektif, terukur, rasional, dan sistematis (Sugiyono, 2009).

\section{Pemilihan Sampel dan Pengumpulan Data}

Pengambilan data penelitian dilakukan antara bulan Januari sampai dengan April 2018, dengan populasi penelitian adalah semua pengusaha UKM di Sentra Batik di Jawa Tengah. Teknik pemilihan sampel dilakukan menggunakan purposive sampling, dengan kriteria pengusaha UKM di sentra batik yang melakukan proses produksi minimal 1 tahun. Hasil pengumpulan data menggunakan kuesioner diperoleh 80 tanggapan yang layak dianalisis.

\section{Instrumen Penelitian}

Instrumen penelitian untuk mempresentasikan terkait dengan variabel yang dipelajari, digunakan kuesioner tertutup, yang didesain untuk mendapatkan jawaban yang sesuai kebutuhan penelitian (Sugiyono, 2009). Pengukuran penilaian responden terhadap variabel-variabel penelitian digunakan skala Likert, dengan lima tingkatan yaitu $1=$ sangat tidak setuju, $2=$ tidak setuju, $3=$ kurang setuju, $4=$ setuju, dan $5=$ sangat setuju.

\section{Operasionalisasi Variabel}

Definisi operasional variabel penelitian ini dapat dijelaskan seperti pada Tabel 1. 
Tabel 1. Operasionalisasi Variabel Penelitian

\begin{tabular}{|c|c|c|c|}
\hline Variabel & Definisi Operasional & Indikator dan Sumber & Pengukuran \\
\hline $\begin{array}{l}\text { Kualitas Strategi } \\
\text { Bisnis }\end{array}$ & $\begin{array}{l}\text { Suatu proses tingkat } \\
\text { perusahaan yang mencakup } \\
\text { berbagai aktivitas untuk } \\
\text { merumuskan misi dan tujuan } \\
\text { perusahaan yang terkait } \\
\text { dengan proses pemasaran. }\end{array}$ & $\begin{array}{l}\text { 1. Integrasi vertikal dan horizontal } \\
\text { 2. Penetrasi pasar } \\
\text { 3. Pengembangan pasar } \\
\text { 4. Pengembangan produk } \\
\text { (Amirkhani \& Reza, 2015) }\end{array}$ & $\begin{array}{l}\text { Skala data } \\
\text { interval (dengan } \\
\text { skala skor 1-5) }\end{array}$ \\
\hline $\begin{array}{l}\text { Etika Perilaku } \\
\text { Penjual }\end{array}$ & $\begin{array}{l}\text { Merupakan gambaran me- } \\
\text { ngenai perilaku penjual } \\
\text { dalam menawarkan jasa. }\end{array}$ & $\begin{array}{l}\text { 1. Mengutamakan kepentingan } \\
\text { pelanggan } \\
\text { 2. Menginformasikan secara benar } \\
\text { 3. Menutup penjualan secara adil } \\
\text { (Chen \& Mau, 2009; Lin \& Wu, 2012) }\end{array}$ & $\begin{array}{l}\text { Skala data } \\
\text { interval (dengan } \\
\text { skala skor 1-5) }\end{array}$ \\
\hline Inovasi Proses & $\begin{array}{l}\text { Kemampuan menggali ide } \\
\text { dan mengimplementasikan- } \\
\text { nya dalam bentuk produk } \\
\text { dan proses. }\end{array}$ & $\begin{array}{l}1 \text { Perubahan bahan baku } \\
2 \text { Perubahan desain produk } \\
3 \text { Perubahan finishing produk } \\
\text { (Aini et al., 2013) }\end{array}$ & $\begin{array}{l}\text { Skala data } \\
\text { interval (dengan } \\
\text { skala skor 1-5) }\end{array}$ \\
\hline $\begin{array}{l}\text { Perspektif orientasi } \\
\text { kewirausahaan }\end{array}$ & $\begin{array}{l}\text { Strategi benefit perusahaan } \\
\text { untuk dapat berkompetisi } \\
\text { secara lebih efektif di dalam } \\
\text { pasar yang sama. }\end{array}$ & $\begin{array}{l}\text { 1. Kemauan berinovasi produk } \\
\text { 2. Tindakan proaktif mengalahkan } \\
\text { pesaing } \\
\text { 3. Berani mengambil risiko } \\
\text { 4. Visi ke masa depan } \\
\text { (Ferdinand \& Killa, 2018) }\end{array}$ & $\begin{array}{l}\text { Skala data } \\
\text { interval (dengan } \\
\text { skala skor 1-5) }\end{array}$ \\
\hline $\begin{array}{l}\text { Adaptabilitas } \\
\text { lingkungan usaha }\end{array}$ & $\begin{array}{l}\text { Kemampuan beradaptasi } \\
\text { terhadap keadaan dan } \\
\text { kekuatan di luar perusahaan } \\
\text { yang berhubungan dengan } \\
\text { konsumen, pemasok, dan } \\
\text { aliansi dalam meningkatkan } \\
\text { rantai pemasok, mempe- } \\
\text { ngaruhi pilihan strategik, dan } \\
\text { menentukan persaingan. }\end{array}$ & $\begin{array}{l}\text { 1. Kemampuan beradaptasi dina- } \\
\text { misme, jumlah dan kecepatan } \\
\text { perubahan lingkungan. } \\
\text { 2. Kemampuan beradaptasi } \\
\text { kelangkaan dan kelimpahan sumber } \\
\text { daya. } \\
\text { 3. Kemampuan beradaptasi } \\
\text { kompleksitas peraturan, persaingan } \\
\text { internasional, teknologi. } \\
\text { 4. Kemampuan beradaptasi } \\
\text { karakteristik industri. } \\
\text { (Arif \& Widodo, 2011; Wulandari, 2009) }\end{array}$ & $\begin{array}{l}\text { Skala data } \\
\text { interval (dengan } \\
\text { skala skor 1-5) }\end{array}$ \\
\hline $\begin{array}{l}\text { Keunggulan } \\
\text { Kompetitif }\end{array}$ & $\begin{array}{l}\text { Strategi benefit perusahaan } \\
\text { dengan melakukan } \\
\text { kerjasama untuk } \\
\text { mewujudkan keunggulan } \\
\text { bersaing yang terus-menerus } \\
\text { sehingga mendominasi pasar } \\
\text { lama maupun baru. } \\
\end{array}$ & $\begin{array}{l}\text { 1. Diferensiasi } \\
\text { 2. Durabilitas } \\
\text { 3. Imitabilitas } \\
\text { 4. Keunggulan biaya } \\
\text { (Manurung, Sugiarto, \& Munas, 2016) }\end{array}$ & $\begin{array}{l}\text { Skala data } \\
\text { interval (dengan } \\
\text { skala skor 1-5) }\end{array}$ \\
\hline Kinerja Bisnis & $\begin{array}{l}\text { Ukuran tingkat pencapaian } \\
\text { kinerja usaha mikro, kecil, } \\
\text { menengah }\end{array}$ & $\begin{array}{l}\text { 1.Pertumbuhan laba } \\
\text { 2.Pertumbuhan pelanggan } \\
\text { 3.Pertumbuhan pangsa pasar } \\
\text { 4.Pertumbuhan penjualan } \\
\text { (Ferdinand \& Killa, 2018; Purnama \& } \\
\text { Setiawan, 2003; Saeidi et al., 2015; } \\
\text { Zhu \& Nakata, 2007) }\end{array}$ & $\begin{array}{l}\text { Skala data } \\
\text { interval (dengan } \\
\text { skala skor 1- } \\
\text { 5) }\end{array}$ \\
\hline
\end{tabular}

\section{Analisis Data}

Data variabel yang didapatkan dalam penelitian ini dianalisis menggunakan pendekatan Partial Least Square Structural Equation Modeling (PLS-SEM). PLS-SEM telah menjadi kecenderungan bagi kalangan para peneliti sebagai alternatif karena mempunyai persyaratan-persyaratan yang lebih longgar serta mudah dipahami (Sarwono \& Narimawati, 2015). PLS-SEM tidak bergantung pada asumsi normalitas karena merupakan statistik non-parametrik (Ghozali \& Latan, 2015). Pendekatan analisis data dengan PLS-SEM berbasis komponen memungkinkan peneliti untuk menguji hubungan sebab akibat antara variabel teramati secara bersamaan (Latan, Chiappetta Jabbour, \& Lopes de Sousa 
Jabbour, 2018). Analisis PLS-SEM memberikan hasil yang kurang kontradiktif daripada analisis regresi dalam hal mendeteksi efek mediasi (Ramli, Latan \& Nartea, 2018). Tiga alasan menggunakan PLS-SEM adalah ukuran sampel kecil, data non-normal, dan kompleksitas model (Latan, 2018).

Secara keseluruhan, analisis data dalam penelitian ini dilakukan dalam empat tahap. Pertama, menilai model pengukuran untuk memastikan setiap indikator dapat diandalkan dan valid. Kedua, menilai model struktural dengan melihat koefisien determinasi $\left(R^{2}\right)$, ukuran efek $\left(f^{2}\right)$, prediktif relevansi dan kebaikan model melalui SRMR, d_ULS dan d_G. Langkah ketiga adalah uji hipotesis yang diajukan menggunakan interval kepercayaan 95\% melalui proses bootstrap (Latan et al., 2018). Tahap terakhir adalah menguji efek mediasi (efek tidak langsung) dalam dua langkah utama, pertama menentukan besar dan signifikansi efek tidak langsung, kedua, menentukan jenis efek mediasi parsial atau mediasi murni (Latan, 2018).

Pada tahap menilai model pengukuran (outer model), convergent validity nilai loading factor setiap indikator dipersyaratkan di atas 0,7 , uji reliabilitas nilai rho_A dan construct reliability (CR) di atas 0,7 dan Average Variance Error (AVE) di atas 0,5.Uji discriminant validity didasarkan nilai akar AVE dipersyaratkan lebih besar daripada korelasi antar konstruk (Ghozali \& Latan, 2015; Hair Jr, Hult, Ringle, \& Sarstedt, 2016; Latan \& Noonan, 2017). Selain itu pada uji discriminant validity juga digunakan Heterotrait-Monotrait (HTMT) Ratio yang dipersyaratkan lebih kecil dari 0,9 (Latan et al., 2018).

Model struktural (inner model) dalam PLS-SEM ditunjukkan dari nilai T-statistik, dimana harus di atas 1,64 untuk penerimaan hipotesis satu ekor (Jogiyanto \& Abdillah, 2009). Persamaan struktural yang dikembangkan adalah sebagai berikut:

$\eta_{1}=\beta_{1} \xi_{1}+\beta_{2} \xi_{2}+\zeta_{1}$

$\eta_{2}=\beta_{3} \xi_{1}+\beta_{4} \xi_{2}+\beta 5_{3} \xi_{3}+\beta_{6} \xi_{4}+\beta_{7} \xi_{5}+\beta_{8} \eta_{1}+\zeta_{2}$

Keterangan:

$\xi 1$ : Kualitas Strategi Bisnis (KSB)

$\xi 2$ : Etika Perilaku Manajemen (ERP)

$\xi 3$ : Inovasi Proses (IP)

$\xi 4$ : Orientasi Kewirausahaan (OK)

5 : Adaptabilitas Lingkungan Usaha (ALU) $\eta 1$ : Keunggulan Kompetitif (KK)

$\eta 2$ : Kinerja Bisnis (KB)

$\beta$ : koefisien jalur

$\zeta$ : residual (unexplained variance)

Untuk mendeteksi pengaruh mediasi keunggulan kompetitif dalam model, studi ini mengadopsi prosedur Baron \& Kenny (1986), yang mengidentifikasinya dalam empat langkah yaitu: (1) variabel independen memiliki pengaruh terhadap variabel dependen, (2) variabel independen memiliki pengaruh terhadap variabel mediasi, (3) variabel mediasi berpengaruh terhadap variabel dependen, dan (4) koefisien regresi pengaruh independen terhadap variabel dependen berkurang secara signifikan atau menjadi tidak signifikan ketika variabel mediasi dimasukkan dalam model. Jika pada langkah keempat signifikan, maka terjadi mediasi secara partial (partial mediation), sedangkan apabila tidak signifikan maka terjadi mediasi secara sempurna (perfect mediation).

\section{Hasil dan Pembahasan}

Analisis statistik inferensial digunakan untuk menguji hipotesis penelitian yang diajukan (Ferdinand, 2014). Analisis data terbagi dua yaitu pengujian model pengukuran dan penilaian model struktural, dilakukan dengan bantuan program SmartPLS v. 3.2.8 (Ringle, Wende, \& Becker, 2015).

\section{Pengujian Model Pengukuran}

Untuk menguji model pengukuran, studi ini menilai berdasarkan nilai loading factor, construct reliability (CR), $\rho_{-} A$, average variance extract (AVE), Heterotrait-Monotrait (HTMT) Ratio, dan korelasi antar variabel. Hasil pengujian model pengukuran (outer model) dapat dijelaskan pada Gambar 2. 


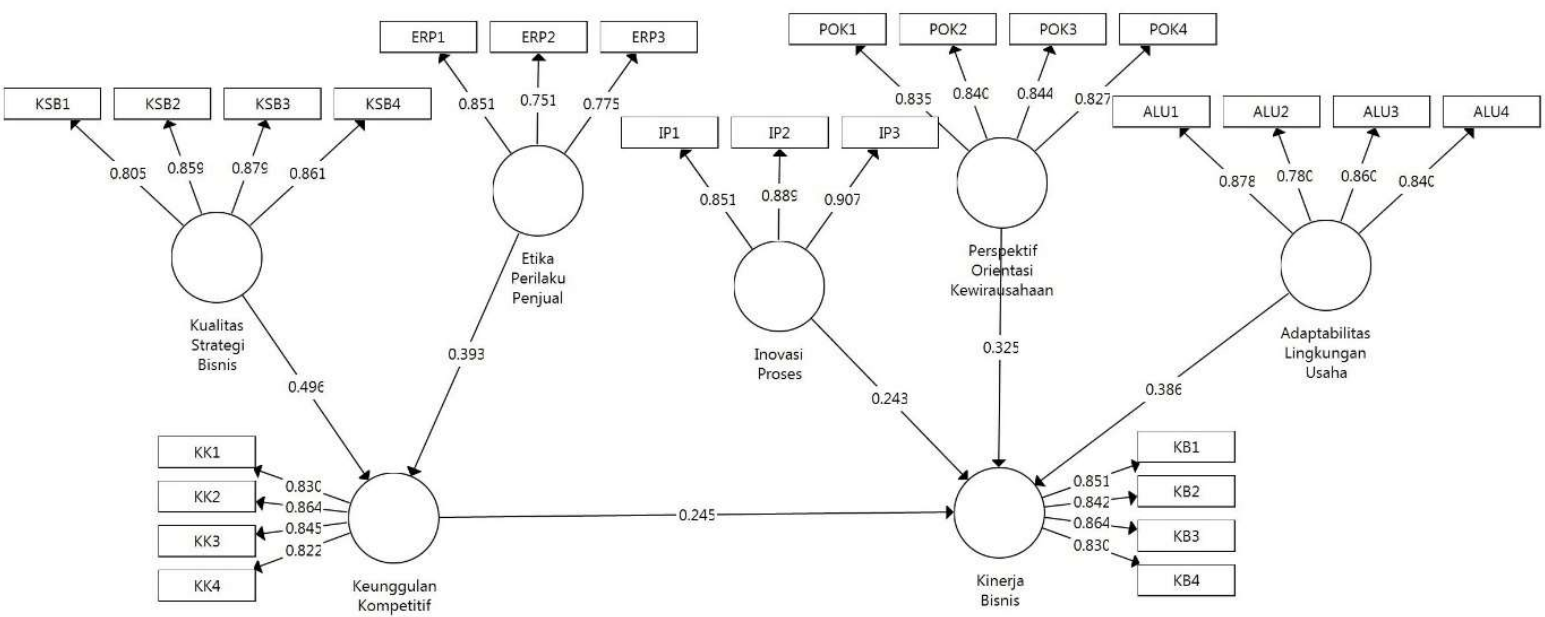

Gambar 2. Evaluasi Outer Model

Tabel 2. Hasil Uji Validitas Konvergen

\begin{tabular}{|c|c|c|}
\hline Konstruk dan Item Pertanyaan & Kode & Loading Factor \\
\hline \multicolumn{3}{|l|}{ Kualitas Strategi Bisnis } \\
\hline Perusahaan memiliki kontrol atas pemasok, distributor, dan pengecer & KSB1 & 0,805 \\
\hline Perusahaan memiliki strategi peningkatan pangsa pasar produksinya & KSB2 & 0,859 \\
\hline Perusahaan memiliki strategi pengembangan pasar ke wilayah baru & KSB3 & 0,879 \\
\hline Perusahaan memiliki strategi menyesuaikan produk dengan pesanan pembeli & KSB4 & 0,861 \\
\hline \multicolumn{3}{|l|}{ Etika Perilaku Penjual } \\
\hline Perusahaan mengutamakan kepentingan pelanggan daripada kepentingan pribadi & ERP1 & 0,851 \\
\hline Perusahaan memberikan informasi secara benar produk yang dijual & ERP2 & 0,751 \\
\hline Perusahaan mengarahkan pelanggan produk terbaik dari aspek kualitas \& harga & ERP3 & 0,755 \\
\hline \multicolumn{3}{|l|}{ Inovasi Proses } \\
\hline Perusahaan melakukan penyesuaian bahan baku untuk menjaga kualitas produk & IP1 & 0,851 \\
\hline Perusahaan melakukan perubahan desain baru sesuai selera pasar & IP1 & 0,889 \\
\hline Perusahaan melakukan perbaikan hasil akhir agar produk lebih berkualitas & IP3 & 0,907 \\
\hline \multicolumn{3}{|l|}{ Perspektif Orientasi Kewirausahaan } \\
\hline Perusahaan memiliki kemauan melakukan proses inovasi produk & POK1 & 0,835 \\
\hline Perusahaan memiliki kemauan proaktif perubahan strategi penjualan dari pesaing & POK2 & 0,840 \\
\hline Perusahaan berani mengambil risiko dengan menciptakan produk unik & POK3 & 0,844 \\
\hline Perusahaan mampu mengelola dan mengembangkan produk di masa mendatang & POK4 & 0,827 \\
\hline \multicolumn{3}{|l|}{ Adaptabilitas Lingkungan Usaha } \\
\hline Perusahaan mampu beradaptasi dengan perubahan kondisi sosial ekonomi politik & ALU1 & 0,878 \\
\hline Perusahaan mampu beradaptasi terhadap kelangkaan \& kelimpahan sumber daya & ALU2 & 0,780 \\
\hline Perusahaan mampu beradaptasi dengan kondisi persaingan usaha yang ketat & ALU3 & 0,860 \\
\hline Perusahaan mampu beradaptasi dengan karakteristik industri & ALU4 & 0,840 \\
\hline \multicolumn{3}{|l|}{ Keunggulan Kompetitif } \\
\hline Perusahaan mampu memproduksi batik yang memiliki ciri khas yang berbeda & KK1 & 0,830 \\
\hline Perusahaan mampu memproduksi batik yang bertahan lama di pasaran & KK2 & 0,864 \\
\hline Perusahaan mampu menghasilkan batik yang susah ditiru pesaing & KK3 & 0,845 \\
\hline Perusahaan mampu membuat batik dengan keunggulan biaya produksi & KK4 & 0,822 \\
\hline \multicolumn{3}{|l|}{ Kinerja Bisnis } \\
\hline Perusahaan mampu meningkatkan pertumbuhan laba penjualan & KB1 & 0,851 \\
\hline Perusahaan mampu meningkatkan pertumbuhan jumlah pelanggan & KB2 & 0,842 \\
\hline Perusahaan mampu meningkatkan pertumbuhan pangsa pasar & KB3 & 0,864 \\
\hline Perusahaan mampu meningkatkan pertumbuhan volume penjualan & KB4 & 0,830 \\
\hline
\end{tabular}


Hasil uji validitas konvergen pada Tabel 2, dapat dijelaskan semua indikator di dalam model telah memiliki loading factor di atas 0,7. Hasil uji reliabilitas pada Tabel 3 dinyatakan memenuhi yang dipersyaratkan karena nilai Cronbach's Alpha, rho_A dan Construct Reliability di atas 0,7 dan Average Variance Error di atas 0,5. Hasil tersebut mengkonfirmasi bahwa semua indikator telah memenuhi validitas konvergen dan reliabilitas, yang menunjukkan mampu mengukur konstruk dan memiliki konsistensi yang baik. Pengujian pada Tabel 4 dijelaskan nilai Akar AVE lebih besar dibandingkan korelasi antar variabel penelitian, yang berarti telah memenuhi uji validitas diskriminan (Ghozali \& Latan, 2015; Hair Jr et al., 2016; Latan \& Noonan, 2017). Studi ini juga menggunakan HTMT untuk validitas diskriminan, dimana dari hasil perhitungan pada Tabel 4 diketahui semua nilai HTMT $<0,90$ sehingga memenuhi batas yang ditetapkan (Latan et al., 2018).

Tabel 3. Hasil Uji Reliabilitas

\begin{tabular}{lcccc}
\hline \multicolumn{1}{c}{ Variables } & \multicolumn{2}{c}{ Cronbach's Alpha } & Construct Reliability & $\begin{array}{c}\text { Average Variance } \\
\text { Error }\end{array}$ \\
\hline Kualitas Strategi Bisnis & 0,874 & 0,883 & 0,913 & 0,725 \\
Etika Perilaku Penjual & 0712 & 0,747 & 0,836 & 0,630 \\
Inovasi Proses & 0,859 & 0,871 & 0,914 & 0,779 \\
Perspektif Orientasi Kewirausahaan & 0,858 & 0,868 & 0,903 & 0,699 \\
Adaptabilitas Lingkungan Usaha & 0,861 & 0,869 & 0,905 & 0,706 \\
Keunggulan Kompetitif & 0,862 & 0,871 & 0,906 & 0,706 \\
Kinerja Bisnis & 0869 & 0,870 & 0,910 & 0,717 \\
\hline
\end{tabular}

Tabel 4. Hasil Uji Validitas Diskriminan

\begin{tabular}{lccccccc}
\hline \multicolumn{1}{c}{ Variables } & ALU & ERP & IP & KK & KB & KSB & POK \\
\hline Adaptabilitas Lingkungan Usaha (ALU) & 0,840 & 0,241 & 0,075 & 0,0539 & 0,751 & 0,274 & 0,521 \\
Etika Perilaku Penjual (ERP) & 0,193 & 0,794 & 0,076 & 0,550 & 0,389 & 0,181 & 0,223 \\
Inovasi Proses (IP) & 0,010 & 0,031 & 0,883 & 0,483 & 0,460 & 0,578 & 0,198 \\
Keunggulan Kompetitif (KK) & 0,476 & 0,449 & 0,148 & 0,840 & 0,790 & 0,611 & 0,582 \\
Kinerja Bisnis (KB) & 0,654 & 0,311 & 0,403 & 0,697 & 0,847 & 0,654 & 0,763 \\
Kualitas Strategi Bisnis (KSB) & 0,234 & 0,112 & 0,505 & 0,540 & 0,574 & 0,851 & 0,433 \\
Perspektif Orientasi Kewirausahaan (POK) & 0,459 & 0,192 & 0,165 & 0,513 & 0,668 & 0,383 & 0,836 \\
\hline
\end{tabular}

Keterangan: nilai diagonal yang tercetak tebal adalah akar AVE, nilai di bawah diagonal adalah korelasi antar variabel, dan nilai di atas diagonal adalah HTMT.

\section{Penilaian Model Struktural}

Berdasarkan pada pengujian model pengukuran sebelumnya diketahui semua indikator memenuhi validitas konvergen, validitas diskriminan, dan reliabilitas, sehingga dapat dilanjutkan pada penilaian model secara keseluruhan dan pengujian hipotesis struktural. Studi ini menggunakan bootstrapping, prosedur nonparametrik yang memungkinkan pengujian signifikansi statistik dari berbagai hasil PLSSEM seperti koefisien jalur, $\mathrm{R}^{2}$, kecocokan model dan lainnya (Ringle et al., 2015). Pada tahap ini dipilih metode bootstrapping dengan subsamples sebesar 5000 dan signifikansi 5\% uji satu sisi, agar diperoleh hasil yang stabil. Hasil penilaian model struktural ditampilkan pada Tabel 5.

Pengujian multikolinieritas model struktural dilakukan dengan melihat nilai Varian Inflation Factor (VIF). Hasil perhitungan pada Tabel 5 diketahui nilai VIF $<3,3$ sehingga dapat dijelaskan tidak terdapat hubungan yang sempurna antar variabel eksogen (Ghozali \& Latan, 2015). Hasil selanjutnya diketahui nilai $\mathrm{R}^{2}$ keunggulan kompetitif sebesar 0,444 masuk klasifikasi moderat, dan nilai $\mathrm{R}^{2}$ kinerja bisnis sebesar 0,738 masuk kriteria substansial/tinggi (Chin, 1998; Hair Jr et al., 2017). Berdasarkan Tabel 5, dapat dilihat nilai $\mathrm{f}^{2}$ berkisar 0,175 sampai dengan 0,437 dengan demikian variabel eksogen memiliki pengaruh besar terhadap variabel endogen (Cohen, 1988). Meskipun uji kecocokan model (model fit) melalui nilai NFI 0,672 diterima secara moderat karena masih di bawah 0,80 (Ringle et al., 
2016), namun nilai Standardized Root Mean Square Residual (SRMR) 0,102 signifikan pada $1 \%$ sehingga telah memenuhi standar (Latan, 2018). Demikian halnya nilai exact fit criteria (kriteria yang tepat) yaitu d_ULS sebesar 3,647 dan d_G sebesar 0,1632 signifikan pada 1\%, sehingga disimpulkan model sesuai dengan data empiris (Dijkstra \& Henseler, 2015).

Tabel 5. Hasil Pengujian Model Struktural

\begin{tabular}{lccccccc}
\hline \multicolumn{1}{c}{ Construct } & VIF & $\mathrm{R}^{2}$ & $\mathrm{f}^{2}$ & SRMR & NFI & d_ULS & d_G \\
\hline Kualitas Strategi Bisnis & 1,013 & & $0,437^{*}$ & & & & \\
Etika Perilaku Penjual & 1,013 & & $0,274^{*}$ & & & & \\
Inovasi Proses & 1,283 & & 0,175 & & & & \\
Perspektif Orientasi & 1,476 & & $0,273^{*}$ & & & & \\
Kewirausahaan & 1,484 & & $0,382^{*}$ & & & & \\
Adaptabilitas Lingkungan Usaha & 1,484 & $0,444^{* *}$ & & & & & \\
Keunggulan Kompetitif & & $0,738^{* *}$ & & $0,102^{* *}$ & 0,672 & $3,647^{* *}$ & $1,632^{* *}$ \\
\hline Kinerja Bisnis & & & & & & & \\
\hline
\end{tabular}

Keterangan: ${ }^{*}$ signifikan pada $\mathrm{p}<0,05 ;{ }^{* *}$ signifikan pada $\mathrm{p}<0,01$.

\section{Pengujian Hipotesis}

Studi ini menguji delapan hipotesis dengan mendasarkan pada nilai koefisien jalur, nilai T-statistik dan signifikansi dengan interval keyakinan $95 \%$. Hasil analisis jalur yang terdiri efek langsung dan efek tidak langsung dapat ditunjukkan pada Tabel 6.

Tabel 6. Pengaruh Antar Variabel

\begin{tabular}{llccc}
\hline Hipotesis & \multicolumn{1}{c}{ Pengaruh } & Koef. $(\beta)$ & T Statistik & $P$ Value \\
\hline H1a & Kualitas Strategi Bisnis $\rightarrow$ Keunggulan Kompetitif & 0,496 & 6,835 & 0,000 \\
H1b & Kualitas Strategi Bisnis $\rightarrow$ Keunggulan Kompetitif $\rightarrow$ Kinerja Bisnis & 0,122 & 2,502 & 0,012 \\
H2a & Etika Perilaku Penjual $\rightarrow$ Keunggulan Kompetitif & 0,393 & 5,205 & 0,000 \\
H2b & Etika Perilaku Penjual $\rightarrow$ Keunggulan Kompetitif $\rightarrow$ Kinerja Bisnis & 0,096 & 2,575 & 0,010 \\
H3 & Inovasi Proses $\rightarrow$ Kinerja Bisnis & 0,243 & 3,544 & 0,000 \\
H4 & Perspektif Orientasi Kewirausahaan $\rightarrow$ Kinerja Bisnis & 0,325 & 4,939 & 0,000 \\
H5 & Adaptabilitas Lingkungan Usaha $\rightarrow$ Kinerja Bisnis & 0,386 & 5,002 & 0,000 \\
H6 & Keunggulan Kompetitif $\rightarrow$ Kinerja Bisnis & 0,245 & 2,815 & 0,005 \\
\hline
\end{tabular}

Berdasarkan hasil perhitungan pengaruh langsung dan pengaruh tidak langsung pada Tabel 6 dapat diketahui semua nilai koefisien jalur $(\beta)$ bernilai positif, nilai T-statistik > T-tabel 1,64 dan nilai $P$-value $<0,05$. Berdasarkan nilai tersebut delapan hipotesis penelitian didukung data empiris sehingga dapat diterima. Temuan ini menjelaskan kualitas strategi bisnis dan etika perilaku penjual secara parsial berpengaruh positif terhadap keunggulan kompetitif. Temuan selanjutnya menunjukkan kualitas strategi bisnis, etika perilaku penjual, inovasi proses, perspektif orientasi kewirausahaan, adaptabilitas lingkungan usaha, dan keunggulan kompetitif secara parsial berpengaruh positif terhadap kinerja bisnis.

\section{Pengujian Peran Mediasi Keunggulan Kompetitif}

Tujuan penelitian ini adalah untuk menganalisis pengaruh peran keunggulan kompetitif pada faktor yang mempengaruhi kinerja bisnis UKM di Sentra Tenun Batik di Jawa Tengah. Hasil perhitungan pengujian peran mediasi tersebut diringkas pada Tabel 7.

Berdasarkan Tabel 7, diketahui setelah variabel keunggulan kompetitif dimasukkan, terdapat penurunan angka estimasi jalur pada pengaruh variabel kualitas strategi bisnis terhadap variabel kinerja bisnis yaitu dari 0,577 menjadi 0,277. Hasil selanjutnya nilai t statistik pada langkah keempat 
didapatkan sebesar 2,544 $>1,64$ dengan probabilitas $0,011<\alpha 5 \%$, sehingga disimpulkan peran mediasi keunggulan kompetitif adalah parsial (partial mediation).

Tabel 7. Peran Mediasi Keunggulan Kompetitif

\begin{tabular}{|c|c|c|c|c|c|}
\hline Prosedur Mediasi & Original Sample & T Statistic & T Table & $P$ Value & Keputusan \\
\hline Langkah 1:KSB $\rightarrow \mathrm{KB}$ & 0,577 & 6,942 & 1,96 & 0,000 & Signifikan \\
\hline Langkah 2: KSB $\rightarrow$ KK & 0,541 & 7,435 & 1,96 & 0,000 & Signifikan \\
\hline Langkah 3: KK $\rightarrow \mathrm{KB}$ & 0,703 & 12,658 & 1,96 & 0,000 & Signifikan \\
\hline Langkah 4: KSB $\rightarrow$ KB* & 0,277 & 2,544 & 1,96 & 0,011 & Signifikan \\
\hline \multicolumn{6}{|c|}{ Keunggulan kompetitif berperan mediasi secara parsial (partial mediation) } \\
\hline Langkah 1:ERP $\rightarrow$ KB & 0,355 & 3,292 & 1,96 & 0,001 & Signifikan \\
\hline Langkah 2: ERP $\rightarrow$ KK & 0,456 & 6,078 & 1,96 & 0,000 & Signifikan \\
\hline Langkah 3: KK $\rightarrow$ KB & 0,703 & 12,658 & 1,96 & 0,000 & Signifikan \\
\hline Langkah 4: ERP $\rightarrow$ KB* & 0,004 & 0,042 & 1,96 & 0,966 & Tidak Signifikan \\
\hline \multicolumn{6}{|c|}{ Keunggulan kompetitif berperan mediasi secara sempurna (perfect mediation) } \\
\hline
\end{tabular}

Keterangan:

KSB: kualitas strategi bisnis, ERP: etika perilaku penjual, KK: keunggulan kompetitif, KB: kinerja bisnis

* Pengaruh setelah variabel mediasi keunggulan kompetitif dimasukkan pada model.

Berdasarkan Tabel 7 diketahui terdapat penurunan angka estimasi jalur pada pengaruh variabel etika perilaku penjual terhadap variabel kinerja bisnis, setelah variabel keunggulan kompetitif dimasukkan, yaitu dari 0,355 menjadi 0,004. Nilai t statistik pada langkah keempat diketahui sebesar $0,042<1,64$ dengan probabilitas 0,966 > $\alpha 5 \%$, sehingga disimpulkan keunggulan kompetitif memiliki peran mediasi secara sempurna (perfect mediation).

\section{Diskusi}

Studi ini menemukan efek positif kualitas strategi pada kinerja bisnis UKM di Sentra Batik di Jawa Tengah. Hasil penelitian ini sejalan dengan studi Wardoyo et al. (2015) yang mengungkapkan konsep pentingnya strategi usaha sebagai cara perusahaan untuk memenangkan persaingan. Proses merumuskan visi dan misi perusahaan dalam mengintegrasikan produksi dan pemasaran akan berdampak positif terhadap pertumbuhan laba, pelanggan, pangsa pasar dan penjualan. Hasil ini menguatkan temuan Calantone et al. (2006), menunjukkan bahwa kualitas strategi bisnis mendorong perusahaan memiliki keunggulan kompetitif, dan memungkinkan perusahaan beradaptasi dengan perubahan lingkungan, sehingga kinerja penjualan meningkat. Hasil studi juga sejalan dengan studi Amirkhani \& Reza (2015) yang menyoroti bahwa perbaikan orientasi strategis dan strategi bisnis mempengaruhi peningkatkan kinerja bisnis. Hasil ini sesuai dengan temuan penelitian Munandar (2016) bahwa strategi yang tepat dalam menjalin kerja sama dengan berbagai pihak untuk melakukan penetrasi dan pengembangan pasar serta pengembangan produk, akan membuat perusahaan memiliki keunggulan dalam memasuki pasar global. Temuan ini memperlemah hasil penelitian Suci (2009) bahwa strategi tidak mampu meningkatkan kinerja.

Temuan selanjutnya penelitian ini menunjukkan etika perilaku penjual menjadi pendorong penting dalam memperoleh keunggulan kompetitif perusahaan menuju kinerja bisnis yang tinggi. Hubungan penting perilaku etis berdasarkan asas keadilan antara pelanggan dan penjual, terbukti mampu mewujudkan keunggulan bersaing secara terus-menerus agar perusahaan menguasai pasar lama maupun memperoleh pasar baru. Praktek bisnis yang dilandasi etika, akan menumbuhkan kepercayaan sehingga berdampak peningkatan loyalitas pelanggan. Hasil penelitian ini mendukung temuan studi sebelumnya Wu (2002), Chen \& Mau (2009), dan Lin \& Wu (2012). Temuan ini juga sejalan dengan pendapat Aziza et al. (2017) bahwa etika telah menjadi titik awal keberhasilan atau kegagalan suatu bisnis. Hasil studinya menjelaskan etika perilaku penjualan merupakan elemen penting yang membantu bagian penjualan dalam mengelola perilaku etis tenaga penjualan perusahaan. 
Hubungan penting inovasi proses dengan kinerja bisnis juga terbukti secara empiris dalam studi ini. Ketika inovasi proses dianggap sebagai kemampuan perusahaan dalam menggali ide serta mengemplimentasikannya dalam bentuk perubahan bahan baku, desain produk, dan finishing sesuai dengan kebutuhan konsumen, maka perusahaan akan memperoleh benefit berupa laba, pelanggan baru, pangsa pasar yang luas dan kenaikan penjualan. Hal ini sejalan dengan studi Hadiyati (2011) yang menyebutkan inovasi dalam menganalisis peluang secara terarah akan berpengaruh terhadap keberhasilan wirausahawan. Hasil penelitian ini konsisten dengan penelitian sebelumnya Aini et al. (2013) bahwa kewirausahaan dan kemampuan inovasi memberikan dampak positif terhadap kinerja bisnis usaha kecil dan menengah. Hasil studi memperlemah riset Lita et al. (2018a) yang menyebutkan inovasi tidak mampu memberikan pengaruh positif terhadap kinerja organisasi pada Usaha Kecil dan Menengah (UKM) industri kerajinan.

Studi ini menjelaskan bahwa perspektif orientasi kewirausahaan sebagai suatu strategi untuk berkompetisi secara efektif, mampu menghasilkan kinerja bisnis usaha kecil menengah di atas ratarata. Hasil ini sesuai dengan pernyataan Hussain et al. (2015) bahwa dalam lingkungan bisnis yang kompetitif perusahaan yang tidak berorientasi kewirausahaan akan menghilang dari pasar dalam waktu singkat. Hasil studi ini memperkaya temuan Masuci (2010) tentang peran orientasi kewirausahaan dalam meningkatkan kinerja bisnis UKM pengusaha wanita. Temuan riset juga sejalan dengan studi sebelumnya yang menunjukkan kemauan berinovasi produk, tindakan proaktif mengalahkan pesaing, keberanian mengambil risiko dan memiliki visi ke depan, terbukti berdampak positif pada peningkatan kinerja bisnis (Gunawan et al., 2013; Ilyas et al., 2017; Kumalaningrum, 2012; Wardoyo et al., 2015). Hasil ini juga sejalan temuan studi Mahmoud (2018) bahwa kinerja bisnis unggul yang diukur dengan tiga indikator: ukuran perusahaan, usia perusahaan dan omset penjualan, dapat ditingkatkan melalui orientasi kewirausahaan. Demikian halnya hasil ini mendukung penelitian Ismanto et al. (2018) bahwa orientasi usaha berdampak positif secara nyata terhadap kinerja UKM di Indonesia.

Hasil penelitian ini memvalidasi temuan studi para pakar akan pentingnya kemampuan adaptasi lingkungan bisnis dalam membangun kinerja bisnis. Hal ini sebagaimana dijelaskan studi Masuci (2010) dan Wulandari (2009) bahwa lingkungan yang kondusif di sekitar UKM memiliki pengaruh langsung untuk meningkatkan kinerja bisnis. Temuan studi ini sesuai pendapat Mahmoud (2018) yang menjelaskan bahwa lingkungan bisnis eksternal seperti intensitas kompetitif, gejolak pasar dan gejolak teknologi, berinteraksi pada pengaruh orientasi pasar terhadap kinerja bisnis. Hal ini sesuai pernyataan Choi (2014) mengingat lingkungan yang tidak pasti, maka kemampuan beradaptasi sangat penting untuk kelangsungan hidup organisasi.

Penelitian ini juga telah menunjukkan betapa pentingnya peran keunggulan kompetitif terhadap kinerja bisnis. Hasil ini menunjukkan bahwa UKM yang melakukan strategi diferensiasi, durabilitas, imitabilitas dan memiliki keunggulan biaya akan mendapatkan pertumbuhan laba, pelanggan, pangsa pasar dan penjualan. Hal ini sesuai dengan pendapat Porter (2008) keunggulan bersaing berkelanjutan merupakan keunggulan yang tidak mudah ditiru sehingga membuat suatu perusahaan dapat merebut dan mempertahankan posisinya sebagai pemimpin pasar. Selain itu sejalan dengan pernyataan Yacob et al. (2017), bahwa perusahaan yang mampu menciptakan keunggulan kompetitif akan memiliki kekuatan untuk bersaing dengan perusahaan lain karena produknya tetap diminati oleh pelanggan. Hasil studi ini memiliki kesamaan dan memperkuat penelitian sebelumnya Budiastuti \& Versia (2011), Zhou et al. (2009), dan Tobing et al. (2018) bahwa keunggulan bersaing memiliki pengaruh yang signifikan terhadap kinerja bisnis. Hasil studi menguatkan temuan penelitian Ismail et al. (2017) bahwa kinerja ekspor dimediasi keunggulan kompetitif. Hasil ini berkebalikan dengan penelitian Echdar (2012), dan Bashor \& Purnama (2017) yang menemukan bahwa kinerja memiliki dampak positif dan signifikan terhadap keunggulan kompetitif.

Orisinalitas penelitian ini adalah yang pertama memasukkan kualitas strategi bisnis dan etika perilaku sebagai upaya peningkatan kinerja perusahaan dengan peran mediasi keunggulan kompetitif. Penelitian ini menjawab studi Wardi et al. (2016) untuk memperluas faktor yang mempengaruhi 
kinerja bisnis, yaitu dengan menambah variabel keunggulan bersaing, dan orientasi kewirausahaan. Demikian halnya penelitian ini melengkapi beberapa studi sebelumnya yang menempatkan peran mediasi keunggulan kompetitif sebatas pada hubungan orientasi kewirausahaan, adaptabilitas lingkungan, dan kreativitas inovasi dengan kinerja bisnis (Mananeke, 2012; Manurung et al., 2016; Meutia, 2013; Mulyanto \& Sugiarti, 2017; Prasetya et al., 2007; Sutapa et al., 2017; Valeria, 2013).

\section{Kesimpulan dan Pengembangan Selanjutnya}

Penelitian ini berfokus pada pentingnya keunggulan kompetitif sebagai strategi bagi Usaha Kecil, dan Menengah (UKM) di sentra batik di Jawa Tengah, dalam upaya meningkatkan kinerja bisnisnya. Secara keseluruhan berdasarkan hasil studi, kualitas strategi bisnis, etika perilaku penjual, inovasi proses, perspektif orientasi kewirausahaan, dan adaptabilitas lingkungan usaha merupakan faktor determinan peningkatan kinerja bisnis UKM. Hal tersebut disebabkan adanya peran mediasi dari keunggulan kompetitif terhadap hubungan positif kualitas strategi dan etika perilaku penjual. Kemampuan UKM menciptakan keunggulan bersaing melalui strategi diferensiasi, durabilitas, imitabilitas, dan biaya kompetitif terbukti berperan nyata dalam mewujudkan pencapaian kinerja bisnis yang diinginkan.

Implikasi manajerial dari studi ini adalah bahwa untuk menciptakan keunggulan kompetitif UKM dapat dilakukan dengan motivasi spiritual, serta menciptakan produk unik/baru di ceruk pasar yang belum dikembangkan pesaing. Upaya meningkatkan kinerja bisnis UKM dapat dicapai melalui peningkatan keunikan produk batik seperti menggunakan teknologi eco printing dalam pewarnaannya.

Hasil penelitian ini diharapkan memiliki implikasi positif pada pengembangan teoritis dalam memperkaya ilmu ekonomi dan bisnis. Keunggulan kompetitif mampu mengisi kesenjangan penelitian antara Beberapa keterbatasan dalam penelitian ini dapat dipertimbangkan bagi studi selanjutnya, seperti peran mediasi keunggulan kompetitif terhadap semua faktor determinan kinerja bisnis. Pengembangan variabel juga dapat dipertimbangkan, seperti teknologi informasi, sumber daya internal, orientasi pasar, orientasi pelanggan, dan budaya perusahaan. Penelitian mendatang juga diharapkan menguji kembali model studi ini pada UKM industri kreatif lainnya, seperti kerajinan tangan, mebel, dan hiburan.

\section{Acknowledgments}

Penelitian ini didukung oleh Hibah Penelitian dari Kementerian Riset, Teknologi, dan Pendidikan Tinggi Republik Indonesia tahun 2018.

\section{Referensi}

Ab Rahman, N. A., \& Ramli, A. (2014). Entrepreneurship management, competitive advantage and firm performances in the craft industry: concepts and framework. Procedia-Social and Behavioral Sciences, 145, 129-137.

Aini, E. K., Long Shen, D. C., Musadieq, M. A., \& Handayani, S. R. (2013). The Role of Innovation Capability on Business Performance At Small Medium Enterprises. Jurnal Profit, 7(1), 101111. doi: http://dx.doi.org/10.9876/10.9876/VOL1ISSN1978-743X.

Ali, A. Y. S., \& Ali, A. H. (2014). Entrepreneurial orientation and performance of women owned and managed micro and small enterprises in Somalia. ZENITH International Journal of Multidisciplinary Research, 4(1), 25-36.

Amirkhani, A. H., \& Reza, A. M. (2015). Investigating the Relationship between Strategic Orientation and Firm ' s Performance Considering the Intermediary Role of Business Strategy. Journal of Management Sciences, 1(8), 152-157. 
Arif, A. L., \& Widodo. (2011). Model Peningkatkan Kinerja Pemasaran dalam Konteks Adaptabilitas Lingkungan. Analisis Manajemen, 5(1), 30-44.

Aziza, N., Aziz, A., Mohtar, A., \& Othman, M. Z. (2017). Sales Pressure and Ethical Sales Climate as Antecedent of Ethical Sales Behaviour amongst Agent. Advanced Journal of Technical and Vocational Education, 1(3), 10-16. doi: 10.26666/rmp.ajtve.2017.3.3

Bank Indonesia. (2015). Profil Bisnis Usaha Mikro, Kecil dan Menengah (UMKM). Jakarta: Lembaga Pengembangan Perbankan Indonesia (LPPI).

Baron, R. M., \& Kenny, D. A. (1986). The Moderator-mediator variable Distinction in Social Psychological Research: Conceptual, Strategic, and Statistical Considerations. Journal of Personality and Social Psychology, 51(6), 1173-1182.

Bashor, C., \& Purnama, C. (2017). Factors Affecting Performance Manager and Its Impact on Competitive Advantage : Studies Small Medium Enterprises ( SMEs ) in The Shoes Industry Mojokerto East Java Province. Mediterranean Journal of Social Sciences, 8(4), 153-162. doi: 10.1515/mjss-2017-0014.

Budiastuti, D., \& Versia. (2011). Pengaruh Kapabiitas Terhadap Keunggulan Kompetitif dan Dampaknya Terhadap Kinerja Perusahaan Pada PT Adi Cipta , Makassar. Binus Business Review, 2(1), 286-292. doi: https://doi.org/10.21512/bbr.v2i1.1135.

Calantone, R. J., Kim, D., Schmidt, J. B., \& Cavusgil, S. T. (2006). The influence of internal and external firm factors on international product adaptation strategy and export performance: A three-country comparison. Journal of Business Research, 59(2), 176-185. doi: 10.1016/j.jbusres.2005.05.001

Chen, M. F., \& Mau, L. H. (2009). The impacts of ethical sales behaviour on customer loyalty in the life insurance industry. Service Industries Journal, 29(1), 59-74. doi: 10.1080/02642060802116339.

Chin, W. W. (1998). The partial least squares approach to structural equation modeling. Modern methods for business research, 295(2), 295-336.

Choi, S. (2014). Learning Orientation and Market Orientation as Catalysts for Innovation in Nonprofit Organizations. Nonprofit and Voluntary Sector Quarterly, 43(2), 393-413. doi: $10.1177 / 0899764012465491$

Cohen, J. (1988). Statistical power analysis for the behavioral sciences 2 nd edn. New Jersey: Erlbaum Associates, Hillsdale.

Dijkstra, T. K., \& Henseler, J. (2015). Consistent and asymptotically normal PLS estimators for linear structural equations. Computational statistics \& data analysis, 81, 10-23.

Djodjobo, C. V., \& Tawas, H. N. (2014). Pengaruh orientasi kewirausahaan, inovasi produk, dan keunggulan bersaing terhadap kinerja pemasaran usaha nasi kuning di kota Manado. Jurnal EMBA: Jurnal Riset Ekonomi, Manajemen, Bisnis dan Akuntansi, 2(3).

Echdar, S. (2012). Strategi Usaha Kecil Ritel Untuk Meningkatkan Kinerja dan Keunggulan Bersaing Berkelanjutan (Studi Kasus di Kota Makassar). Ekuitas: Jurnal EKonomi dan Keuangan, 18(3), 311-329. DOI: http://dx.doi.org/10.24034/j25485024.y2014.v18.i3.146

Faisal, A., Hermawan, A., \& Arafah, W. (2018). The Influence of Strategic Orientation on Firm Performance Mediated by Social Media Orientation at MSMEs. International Journal of Science and Engineering Invention, 4(08), 22-31. doi https://doi.org/10.23958/ijsei/vol04i08/03 
Ferdinand, A. (2003). Keunggulan Differensiasi dan Kinerja Pemasaran. Jurnal Bisnis Strategi, 12, 118.

Ferdinand, A. (2014). Metode Penelitian Manajemen Pedoman Penelitian Untuk Penulisan Skripsi Tesis dan Disertasi Ilmu Manajemen: Semarang: Badan Penerbit Universitas Diponegoro.

Ferdinand, A. T., \& Killa, M. F. (2018). The Pareto sales network asset: A networked power perspective. Business: Theory and Practice, 19, 103-113. doi: 10.3846/btp.2018.11.

García-Rodríguez, F. J., Gil-Soto, E., Ruiz-Rosa, I., \& Gutiérrez-Taño, D. (2017). Entrepreneurial potential in less innovative regions: the impact of social and cultural environment. European Journal of Management and Business Economics, 26(2), 163-179. doi: 10.1108/EJMBE-072017-010.

Ghozali, I., \& Latan, H. (2015). Partial Least Squares, Konsep, Teknik Dan Aplikasi Menggunakan Program Smartpls 3.0 Untuk Penelitian Empiris.

Gunawan, T., Jacob, J., \& Duysters, G. (2013). Entrepreneurial orientation and network ties: Innovative performance of SMEs in an emerging-economy manufacturing cluster. Unpublished article, submitted to Maastricht School of Management and Technical University of Eindhoven, the Netherlands.

Gupta, V. K., \& Batra, S. (2016). Entrepreneurial orientation and firm performance in Indian SMEs: Universal and contingency perspectives. International Small Business Journal, 34(5), 660682.doi: https://doi.org/10.1177/0266242615577708.

Hadiyati, E. (2011). Kreativitas dan Inovasi Berpengaruh Terhadap Kewirausahaan Usaha Kecil. Jurnal Manajemen dan Kewirausahaan, 13(1), 8-16. doi: https://doi.org/10.9744/jmk.13.1.8-16.

Hair Jr, J. F., Hult, G. T. M., Ringle, C., \& Sarstedt, M. (2016). A primer on partial least squares structural equation modeling (PLS-SEM): Sage Publications.

Hair Jr, J. F., Sarstedt, M., Ringle, C. M., \& Gudergan, S. P. (2017). Advanced issues in partial least squares structural equation modeling: SAGE Publications.

Han, J. K., Kim, N., \& Srivastava, R. K. (1998). Market orientation and organizational performance: is innovation a missing link? The Journal of marketing, 62, 30-45. doi: 10.2307/1252285.

Hatta, I. H. (2015). Orienasi Pasar, Orientasi Kewirausahaan, Kapabilitas Pemasaran dan Kinerja Pemasaran. Jurnal Aplikasi Manajemen, 13(4), 653-661.

Hughes, M., \& Morgan, R. E. (2007). Deconstructing the relationship between entrepreneurial orientation and business performance at the embryonic stage of firm growth. Industrial marketing management, 36(5), 651-661. doi: https://doi.org/10.1016/ j.indmarman.2006.04.003.

Hussain, J., Abbas, Q., \& Khan, M. A. (2017). Entrepreneurial Orientation and Performance: The Moderating Effect of Market Orientation. Journal for Academic \& Corporate Studies, 7(1), 918.

Hussain, J., Ismail, K., \& Shah, F. A. (2015). The Effect of Market and Entrepreneurial Orientations on Organizational Performance: Study of Malaysian SMEs. City University Research Journal, 05(02), 203-218.

Ilyas, G. B., Munir, A. R., \& Sobarsyah, M. (2017). Role of Strategic Leadership , Entrepreneurial Orientation, and Innovation on Small and Medium Enterprises Performance. International Journal of Economic Research, 14(15), 61-72. 
Irjayanti, M., \& Azis, A. M. (2012). Barrier factors and potential solutions for Indonesian SMEs. Procedia Economics and Finance, 4, 3-12.

Ismail, D., Alam, S. S., \& Hamid, A. (2017). Trust , Commitment, and Competitive Advantage in Export Performance of SMEs. Gajah Mada International of Business, 19(1), 1-18.

Ismanto, H., Aziz, S., \& Irawan, W. (2018). Peran Karakteristik Pemilik , Hubungan Dengan Pelanggan , Komitmen Perilaku, dan Orientasi Usaha Terhadap Kinerja Keuangan UKM. Jurnal Siasat Bisnis, 22(1), 76-91. doi: 10.20885/jsb.vol22.iss1.art5

Jansen, J. J. P., Van Den Bosch, F. A. J., \& Volberda, H. W. (2006). Exploratory Innovation, Exploitative Innovation, and Performance: Effects of Organizational Antecedents and Environmental Moderators. Management Science, 52(11), 1661-1674. doi: 10.1287/mnsc. 1060.0576

Jermias, J. (2006). Competitive Intensity as a Quasi- Moderator of the Relationship between Innovative Efforts and Performance. Gajah Mada International of Business, 8(3), 281-299.

Jogiyanto, H. M., \& Abdillah, W. (2009). Konsep dan Aplikasi PLS (Partial Least Square) untuk Penelitian Empiris. 'Yogyakarta: BPFE Fakultas Ekonomika dan Bisnis UGM.

Kirca, A. H., Jayachandran, S., \& Bearden, W. O. (2005). Market Orientation: A Meta-Analytic Review and Assessment of Its Antecedents and Impact on Performance. Journal of Marketing, 69(2), 24-41. doi: 10.1509/jmkg.69.2.24.60761

Kumalaningrum, M. P. (2012). Lingkungan Bisnis, Orientasi Kewirausahaan, Orientasi Pasar, dan Kinerja Usaha Mikro, Kecil dan Menengah. Jurnal Riset Manajemen dan Bisnis, 7(1), 45-59.

Kusumawardhani, A., McCarthy, G., \& Perera, N. (2009). Framework of entrepreneurial orientation and networking: a study of SMEs performance in a developing country. Proceedings of the Australian and New Zealand Academy of Management Conference. (pp.1-16). Adelaide, Australia: Australian and New Zealand Academy of Management.

Latan, H. (2018). PLS Path Modeling in Hospitality and Tourism Research: The Golden Age and Days of Future Past.

Latan, H., \& Noonan, R. (2017). Partial Least Squares Path Modeling: Basic Concepts, Methodological Issues and Applications: Springer.

Latan, H., Chiappetta Jabbour, C. J., \& Lopes de Sousa Jabbour, A. B. (2018). 'Whistleblowing Triangle': Framework and Empirical Evidence. Journal of Business Ethics, 1-16. doi: 10.1007/s10551-018-3862-x

Lin, S.-H., \& Wu, H. (2012). Effects of Ethical Sales Behavior Considered through Transaction Cost Theory : To Whom Is the Customer Loyal ? The Journal of International Management Studies, 7(1), 31-40.

Lita, R. P., Meuthia, \& Faisal, R. F. (2018a). Model Keterkaitan Orientasi Pasar , Kepemimpinan Transformasional , Inovasi dan Kinerja Organisasi pada Industri Kerajinan di Sumatera Barat. Jurnal Siasat Bisnis, 22(1), 38-61. doi: 10.20885/jsb.vol22.iss1.art3

Lita, R. P., Meuthia, M., \& Faisal, R. F. (2018b). SME's Performance of Creative Industries Supporting Tourism In Indonesia: Market Orientation, Learning Orientation and Organizational Innovativeness as Determinants. Academy of Marketing Studies Journal, 22(1), 1-18.

Mahmoud, M. A. (2018). Market Orientation and Business Performance among SMEs in Ghana. International Business Research, 4(1), 241-251. 
Mananeke, L. (2012). the Determining Factors of the Competitive Advantage and Business Performance in the Coastal Communities in North Minahasa Regency. Journal of Economics, Business, and Accountancy Ventura, 15(3), 409-422. doi: 10.14414/jebav.v15i3.111

Manurung, M. T., Sugiarto, J., \& Munas, B. (2016). Membangun Keunggulan Bersaing untuk Meningkatkan Kinerja Bisnis pada Industri Kecil Menengah Tenun Ikat di Troso, Jepara. Jurnal Bisnis Strategi, 25(2), 171-184. doi: https://doi.org/10.14710/jbs.25.2.171-182

Masuci, R. (2010). Analisis Pengaruh Lingkungan dan Gaya Kepemimpinan Pengusaha Wanita dalam Membangun Orientasi Kewirausahaan untuk Meningkatkan Kinerja Bisnis UKM (Studi Pada UKM yang Dibina Dinas Perindustrian dan Perdagangan Kota Semarang). Jurnal Bisnis Strategi, 19(1), 71-90. doi: https://doi.org/10.14710/jbs.19.1.71-92

Meutia. (2013). Improving Competitive Advantage and Business Performance through the Development of Business Network, Adaptability of Business Environment and Innovation Creativity. Aceh International Journal of Social Sciences, 2(1), 11-20. doi: https://doi.org/10.12345/aijss.2.1.1359

Mulyanto, H., \& Sugiarti, S. (2017). Aset Strategik, Adaptabilitas Lingkungan Dan Organizational Citizenship Behavior Dalam Mempengaruhi Daya Saing Serta Dampaknya Pada Kinerja Perusahaan. Jurnal Manajemen \& Kewirausahaan, 13(2), 101-112.

Munandar, A. (2016). The Strategy Development and Competitive Advantages of Micro Small Medium Entreprise Business Institution Toward Regional Development. AdBispreneur, 1(2), 103-112. doi: https://doi.org/10.24198/adbispreneur.v1i2.10233

Nur, N., Surachman, Salim, U., \& Djumahir. (2014). Entrepreneurship Orientation, Market Orientation, Business Strategy, Management Capabilities On Business Performance: Study At Small And Medium Enterprise Printing In Kendari. International Journal of Business and Management Invention ISSN (Online), 3(12), 8-15.

Nurlina, N., \& Darsono, N. (2017). The role of competitive advantage in mediating the effect of entrepreneurial orientation and knowledge management toward business performance. Proceedings of AICS-Social Sciences, 7, 394-405.

O'Donnell, A., Gilmore, A., Carson, D., \& Cummins, D. (2002). Competitive advantage in small to medium-sized enterprises. Journal of strategic marketing, 10(3), 205-223. doi: https://doi.org/10.1080/09652540210151388.

Palalic, R., \& Busatlic, S. (2015). Exploratory research on relationship between entrepreneurial orientation dimensions and business performance and growth of fast and slow growing small and medium enterprises in Bosnia and Herzegovina. International Journal of Business and Management, 10(2), 15-30. doi:10.5539/ijbm.v10n2p15.

Porter, M. E. (2008). Keunggulan Bersaing, cetakan kedua, terjemahan. Jakarta: Penerbit Erlangga.

Prasetya, G. L. H., Rahardja, E., \& Hidayati, R. (2007). Membangun Keunggulan Kompetitif Melalui Aliansi Stratejik Untuk Meningkatkan Kinerja Perusahaan (Studi Kasus Pada PT. Pos Indonesia Wilayah VI Jateng Dan DIY). Jurnal Studi Manajemen \& Organisasi, 4(2), 1-19. doi: https://doi.org/10.14710/jsmo.v4i2.4245.

Purnama, N. b., \& Setiawan, H. (2003). Analisis Pengaruh Sumber-sumber Keunggulan Bersaing Bidang Pemasaran Terhadap Kinerja Perusahaan Manufaktur di Indonesia. Jurnal Siasat Bisnis, 2(8), 105-130. 
Putri, P. I. P., Yasa, N. N. K., \& Rahyuda, I. K. (2016). The Role of Innovation in Mediating Market Orientation To Company Performance. Jurnal Dinamika Manajemen, 7(2), 105-116. doi: 10.15294/jdm.v7i2.8195.

Rahayu, N. S., \& Purwani, K. (2012). Strategy Of Enhancing The Competitiveness of Leather' S SMEs : Study In Manding Yogyakarta. Junral Inovasi dan Kewirausahaan, 1(2), 129-134. doi: https://doi.org/10.20885/ajie.vol1.iss2.art7.

Ramli, N. A., Latan, H., \& Nartea, G. V. (2018). Why should PLS-SEM be used rather than regression? Evidence from the capital structure perspective. In Partial Least Squares Structural Equation Modeling. 267(February), 171-209. doi: 10.1007/978-3-319-71691-6.

Rauch, A., Wiklund, J., Lumpkin, G. T., \& Frese, M. (2009). Entrepreneurial orientation and business performance: An assessment of past research and suggestions for the future. Entrepreneurship theory and practice, 33(3), 761-787. doi: https://doi.org/10.1111/j.1540-6520.2009.00308.x.

Reinartz, W., Krafft, M., Hoyer, W. D., Reinartz, W., Krafft, M., \& Hover, W. D. (2010). Process : Its Relationship Management Measurement and. Journal of Marketing Reseach, 41(3), 293-305.

Retas. (2017). Gairah Fashion Indonesia di Panggung Dunia Kiprah Para Desainer Muda Memasuki Pasar Global.

Ringle, C. M., Wende, S., \& Becker, J.-M. (2015). SmartPLS 3. Boenningstedt: SmartPLS GmbH, http://WWW. smartpls. com.

Rum, M. (2013). Locus of control, Innovation, Performance Of The Business People In The Small Business And Medium Industries In South Sulawesi. Journal of Economics, Business \& Accountancy Ventura, 15(3), 373-388. doi: 10.14414/jebav.v15i3.108.

Saeidi, S. P., Sofian, S., Saeidi, P., Saeidi, S. P., \& Saaeidi, S. A. (2015). How does corporate social responsibility contribute to firm financial performance? The mediating role of competitive advantage, reputation, and customer satisfaction. Journal of Business Research, 68(2), 341350. doi: 10.1016/j.jbusres.2014.06.024

Sarwoko, E. (2008). Kajian Faktor-Faktor Penentu Keberhasilan Small Business. Jurnal Ekonomi Modernisasi, 4(3), 226-239.

Sarwono, J., \& Narimawati, U. (2015). Membuat Skripsi, Tesis, dan Disertasi dengan Partial Least Square SEM (PLS-SEM): Yogyakarta: CV Andi Offset.

Sekaran, U. (2006). Research Methods for Business Edisi 4. Jakarta: Salemba Empat.

Setyawati, \& Abrilia, H. (2013). Pengaruh Orientasi Kewirausahaan Dan Orientasi Pasar Terhadap Kinerja Perusahaan Melalui Keunggulan Bersaing dan Persepsi Ketidakpastian Lingkungan Sebagai Prediksi Variabel Moderasi (Survey pada UMKM Perdagangan di Kabupaten Kebumen). Jurnal Fokus Bisnis, 12(02), 20-32.

Setyawati, A., \& Helmy, I. (2018). Pengaruh Proving Goal Orientation dan Selling Experience Terhadap Kinerja Tenaga Penjualan dengan Perilaku Penjualan Adaptif Sebagai Variabel Mediasi (Studi pada Lembaga Keuangan Mikro di Kabupaten Kebumen). PRO BISNIS, 11(1), $31-43$.

Sijabat, F. N. (2018). Entrepreneurial Orientation, Barriers, Business Networks, and Internationalization Readiness: A Conceptual Framework for the SMEs. International Journal of Academic Research in Accounting, Finance and Management Sciences 8(3): 95-102, http://dx.doi.org/10.6007/IJARAFMS/v8-i3/4533 (DOI: 10.6007/IJARAFMS/v8-i3/4533). 
Singh, R. K., Garg, S. K., \& Deshmukh, S. G. (2009). The competitiveness of SMEs in a globalized economy: Observations from China and India. Management research review, 33(1), 54-65. doi: doi:10.1108/01409171011011562.

Sopandi, E. (2017). Analisis Keunikan Sumberdaya Dan Strategi Keunggulan Bersaing Produk Kreatif Bambu (Studi pada Saung Angklung Udjo Bandung Jawa Barat). Journal of Management and Business Review, 14(2), 176-205.

Suci, R. P. (2009). Peningkatan Kinerja Melalui Orientasi Kewirausahaan , Kemampuan Manajemen , dan Strategi Bisnis (Studi pada Industri Kecil Menengah Bordir di Jawa Timur). Jurnal Manajemen dan Kewirausahaan, 11(1), 46-58. doi: https://doi.org/10.9744/ jmk.11.1.pp.\%2046-58.

Sugiyono. (2009). Metode Penelitian Bisnis (Pendekatan Kuantitatif, Kualitatif dan R\&D): Bandung: CV Alfabeta.

Sukesti, F., \& Iriyanto, S. (2011). Meningkatkan Komoditas Unggulan Ekspor UKM Dalam Rangka Pengembangan Ekonomi Daerah (Studi pada UKM di Jawa Tengah). In Seminar Nasional IImu Ekonomi Terapan Fakultas Ekonomi UNIMUS 1(1), 86-92.

Sutapa, Mulyana, \& Wasitowati. (2017). The Role of Market Orientation, Creativity and Innovation in Creating Competitive Advantages and Creative Industry Performance. Jurnal Dinamika Manajemen, 8(2), 152-166. doi: 10.15294/jdm.v8i2.12756.

Sutono. (2005). Pengaruh Perilaku Etis dan Orientasi Pelanggan Terhadap Kinerja Tenaga Penjual (Sebuah Studi pada Industri Asuransi Jiwa di Semarang). Jurnal Sains Pemasaran Indonesia, IV(2), 131-152. doi: https://doi.org/10.14710/jspi.v4i2.131-152.

Sutopo, \& Sutono. (2004). Pengaruh Perilaku Etis dan Orientasi Pelanggan Terhadap Kinerja Penjualan. Jurnal Bisnis Strategi, 13, 171-189. DOI: https://doi.org/10.14710/jbs.13.2.171189.

Tambunan, T.T.H (2011). Development of small and medium enterprises in a developing country: The Indonesian case. Journal of Enterprising Communities: People and Places in the Global Economy, 5(1), 68-82. doi:https://doi.org/10.1108/17506201111119626.

Teeratansirikool, L., Siengthai, S., Badir, Y., \& Charoenngam, C. (2013). Competitive strategies and firm performance: the mediating role of performance measurement. International Journal of Productivity and Performance Management, 62(2), 168-184. doi: 10.1108/ 17410401311295722.

Tobing, D. S. K., Fathorazz, M., \& Wulandari, G. A. (2018). Mapping the Competitive Advantage of SMEs in East Java, Indonesia. Jurnal Dinamika Manajemen, 9(1), 23-32. doi: 10.15294/jdm.v9i1.14649.

Valeria, N. P. (2013). Membangun Kinerja Bisnis Melalui Keunggulan Bersaing pada UKM Manufaktur (Studi Empirik Pada Industri Logam di Kecamatan Ceper, Kabupaten Klaten ). Jurnal Bisnis Strategi, 22(1), 133-142. doi: https://doi.org/10.14710/jbs.22.1.133-142.

Wardoyo, P., Rusdianti, E., \& Purwantini, S. (2015). Pengaruh Orientasi Kewirausahaan Terhadap Strategi Usaha dan Kinerja Bisnis UMKM Di Desa Ujung-Ujung, Kec. Pabelan, Kab. Semarang. Sustainable Competitive Advantage, 5(1), 1-19.

Wardi, Y. K., Mangunwihardjo, S., \& Perdana, M. S. (2016). Membangun Strategi Bisnis Melalui Faktor Manajerial Sebagai Pemilik dan Lingkungan Bisnis Eksternal dalam Meningkatkan Kinerja. Jurnal Bisnis Strategi, 25(2), 82-94. 
Widodo. (2011). Peningkatan Kinerja Organisasi Melalui Perencanaan Strategi. Siasast Bisnis, 15(1), 83-97.

Wu, C. F. (2002). The relationship of ethical decision-making to business ethics and performance in Taiwan. Journal of Business Ethics, 35(3), 163-176. doi: 10.1023/A:1013853107403.

Wulandari, A. (2009). Pengaruh Lingkungan Eksternal dan Lingkungan Internal Terhadap Orientasi Wirausaha dalam Upaya Meningkatkan Kinerja Perusahaan. Jurnal Pengembangan Wiraswasta, 11(2), 142-152.

www.dinkop-umkm.jatengprov.go.id. (2018). Dinas Koperasi dan Usaha Mikro Kecil dan Menengah Jawa Tengah. Retrieved 29 April 2018

Yacob, S., Octavia, A., Mayrina, \& Hasan, H. (2017). Do Really Social Commerce Creating For Competitive Advantage On Small Medium Enterprises (SMEs) Business Performance?: Evidence From Jambi, Indonesia. Paper presented at the The Sixth International Conference on Entrepreneurship and Business Management.

Zhou, K. Z., Brown, J. R., \& Dev, C. S. (2009). Market orientation, competitive advantage, and performance: A demand-based perspective. Journal of Business Research, 62(11), 1063-1070. doi: 10.1016/j.jbusres.2008.10.001

Zhu, Z., \& Nakata, C. (2007). Reexamining The Link Between Customer Orientation and Business Performance : The Role of Information Systems. Journal of Marketing Theory and Practice, 15(3), 187-203. doi: 10.2753/MTP1069-6679150301. 